\title{
Efektivitas Video Digital Storytelling terhadap Hasil Belajar Siswa Kelas X pada Materi Trigonometri
}

\author{
Denok Julianingsih ${ }^{1 *}$, Endang Krisnawati ${ }^{2}$ \\ 1,2 STKIP Bina Insan Mandiri \\ *denokjulianingsih@stkipbim.ac.id
}

Diterima: Oktober 2019. Disetujui: Desember 2019. Dipublikasikan: Januari 2020.

\begin{abstract}
ABSTRAK
Penelitian ini bertujuan untuk mengetahui: 1) perbedaan hasil belajar siswa yang diajar menggunakan video Digital Storytelling dengan siswa yang diajar tanpa menggunakan video Digital Storytelling, 2) efektivitas penggunaan video Digital Storytelling terhadap hasil belajar siswa. Penelitian ini dilakukan di SMA Muhammadiyah 4 pada siswa kelas X. Penelitian ini merupakan penelitian eksperimen dengan teknik probability sampling. Desain pada penelitian ini menggunakan model pretest-posttest control group design. Pengumpulan data dengan menggunakan soal pretest dan posttest menggunakan skor pretest dan skor posttest. Teknik analisa data yang digunakan menggunakan analisis deskriptif dan analisis inferensial. Hasil penelitian menunjukkan ada perbedaan rata-rata hasil belajar siswa yang diajar menggunakan video Digital Storytelling dengan siswa yang diajar tanpa menggunakan video Digital Storytelling. Perbedaan rata-rata hasil belajar antara post-test eksperimen dengan post-test kontrol dari hasil uji Independent Sample Test tersebut adalah 8,678 sehingga media Digital Storytelling efektif digunakan dalam pembelajaran trigonometri. Penggunaan video Digital Storytelling terbukti efektif digunakan pada pembelajaran trigonometri karena berdasarkan hasil uji independent sample test menunjukkan dapat meningkatkan hasil belajar siswa.

Kata kunci: media pembelajaran, video digital storytelling, hasil belajar.
\end{abstract}

\begin{abstract}
This study aims to determine: 1) differences in student learning outcomes taught using Digital Storytelling videos and students taught without using Digital Storytelling videos, 2) the effectiveness of using Digital Storytelling videos on student learning outcomes. This research was conducted at Muhammadiyah 4 High School in class X students. This study was an experimental study with sampling using probability sampling techniques. The design in this study used a pretest - posttest control group design model. Data collection using pretest scores and posttest scores. The data analysis technique used is descriptive analysis and inferential analysis. The results showed there were differences in the average learning outcomes of students who were taught using Digital Storytelling videos with students who were taught without using Digital Storytelling videos. The difference in average learning outcomes is 8,678 so that the Digital Storytelling media is effectively used in trigonometric learning.
\end{abstract}

Keywords: learning media, digital video storytelling, learning outcomes.

How to Cite: Julianingsih, D. \& Krisnawati, E. (2020). Efektivitas Video Digital Storytelling terhadap Hasil Belajar Siswa Kelas X pada Materi Trigonometri. Journal of Medives: Journal of Mathematics Education IKIP Veteran Semarang, 4(1), 129-139. 


\section{PENDAHULUAN}

Perkembangan teknologi saat ini berjalan sangat cepat. Mulai dari anakanak sampai dengan orang dewasa hampir tidak terlepas dari adanya teknologi. Teknologi informasi dan komunikasi menjadi salah satu dari perkembangan digital di era 4.0 saat ini. Kegiatan komunikasi yang awalnya menggunakan peralatan-peralatan yang cukup rumit, kini relatif lebih mudah karena sudah digantikan oleh mesinmesin yang lebih otomatis. Tidak cukup disitu, bahkan teknologi informasi dan komunikasi memiliki andil yang cukup besar dalam dunia pendidikan khususnya dalam hal proses belajar mengajar. Hal ini sesuai dengan pendapat Eggen \& Kauchak (2012) yang menyatakan bahwa pendidikan masa kini lebih ditekankan pada penggunaan teknologi. Atas dasar itulah maka perlunya sebuah teknologi informasi yang menjadi bagian utama dalam dunia pendidikan.

Dalam memasuki era tersebut peran guru sangat penting demi terciptanya pendidikan yang dinamis sesuai dengan era perkembangan zaman. Untuk itulah guru perlu memiliki strategi, metode, maupun media pembelajaran demi meningkatkan aktivitas siswa selama proses pembelajaran. Siswa yang aktif selama proses pembelajaran berlangsung, diharapkan dapat sejalan dengan meningkatnya prestasi siswa. Aktivitas siswa di kelas dapat terbentuk salah satunya dengan menjalin komunikasi aktif dengan siswa. Komunikasi merupakan bagian yang sangat penting untuk membangun interaksi antara guru dan siswa. Salah satu cara agar guru dan siswa dapat berkomunikasi dengan baik adalah dengan penggunaan media saat proses belajar mengajar. Pendapat ini sesuai dengan yang diungkapkan oleh Djamarah (2010) yang menyatakan bahwa metode dan media yang digunakan dalam pembelajaran seharusnya memenuhi beberapa kriteria yaitu: 1) dapat menarik minat dan motivasi belajar siswa, 2) sesuai dengan tujuan pembelajaran, 3) dapat meningkatkan berbagai keterampilan yang dimiliki oleh siswa, dan 4) dapat meningkatkan keaktifan siswa dalam belajar di kelas.

Berdasarkan hasil dari wawancara bersama guru matematika di salah satu sekolah swasta di SMA Muhammadiyah 4 Surabaya, pada saat pembelajaran matematika di kelas didapatkan siswa yang kurang aktif. Hal ini dikarenakan tidak adanya komunikasi dua arah yang terjadi antara guru dengan siswa saat mengikuti pembelajaran matematika, sehingga siswa tidak berperan aktif dalam pembelajaran. Dapat dilihat pula pada saat pelaksanaan observasi siswa nampak mengantuk dan terlihat sangat jenuh. Hal ini dikarenakan saat pembelajaran matematika, Guru tidak menggunakan media yang dapat menarik perhatian siswa untuk belajar. Minimnya penggunaan media saat pembelajaran menjadi salah satu faktor utama rendahnya nilai siswa pada mata pelajaran matematika materi trigonometri yang sebagian besar siswa menganggap materi ini sangat membosankan dan tidak ada manfaatnya dalam kehidupan sehari-hari. Selain itu, beberapa kegagalan siswa pada pembelajaran trigonometri disebabkan karena kurangnya kemampuan bernalar siswa terhadap permasalahan yang disajikan dan juga disebabkan 
karena kurangnya kemampuan prosedural maupun strategi yang dimiliki siswa dalam menyelesaikan soal. (Gerhana dalam Krisnawati, 2019).

Pada dasarnya dalam proses pembelajaran, penggunaan dan pengembangan media pembelajaran sangat diperlukan. Hal ini dikarenakan penggunaan media sederhana berupa buku teks yang diberikan secara terus menerus akan dapat menimbulkan kebosanan pada diri siswa dan berkurangnya motivasi belajar siswa (Gunawan dalam Prananta, 2017). Pendapat ini diperkuat oleh Russel (dalam Anggadewi, 2017) yang menyatakan bahwa tujuan penggunaan media untuk memudahkan komunikasi dan belajar. Pemanfaatan media ini akan efektif apabila guru mampu menganalisis karakteristik siswa dan bagaimana siswa belajar.

Salah satu media yang tepat digunakan sesuai dengan era perkembangan digital saat ini adalah dengan menggunakan media audio visual yaitu Digital Storytelling. Media audio visual merupakan media yang memiliki kemampuan lebih. Media ini mencakup dua indera manusia sekaligus yaitu indera pendengaran dan indera penglihatan (Dick and Carey dalam Purwanti, 2015).

Sedangkan Digital Storytelling sendiri merupakan suatu media, di mana terdapat pengubahan cerita ke dalam bentuk multimedia. Robin dan Dreon (dalam Rohmawati, 2014) menyatakan bahwa Digital Storytelling merupakan seni bercerita dengan beberapa gabungan dari grafik digital, teks, rekaman narasi suara, video, dan musik yang memberikan informasi pada topik atau pengalaman tertentu dengan durasi waktu tertentu yang dikemas dalam format digital.

Ditinjau dari sisi kognitif penerapan Digital Storytelling cukup berpengaruh pada prestasi belajar siswa pada mata pelajaran tertentu (Oktafiani dalam Prananta, 2016). Beberapa penelitian lain juga mengungkapkan bahwa Digital Storytelling cukup efektif digunakan dalam proses belajar mengajar baik oleh guru maupun siswa (Smeda, Dakich, \& Sharda dalam Prananta, 2016).

Media Digital Storytelling ini tidak hanya membuat siswa menjadi tertarik terhadap pembelajaran yang sedang berlangsung tetapi juga komunikasi antara guru dengan siswa dapat terjalin dengan baik. Selain itu, penggunaan media video Digital Storytelling dapat melatih keterampilan anak dalam berbicara, memecahkan suatu masalah dan menilai sesuatu hal.

Hal ini diperkuat oleh pendapat Heriyana dan Maureen dalam (Nurul Asri, 2017) yang menyatakan bahwa pembelajaran dengan menggunakan Digital Storytelling dapat meningkatkan beberapa keterampilan siswa di antaranya adalah keterampilan meneliti, keterampilan menulis, keterampilan berwawancara, keterampilan menggunakan teknologi, keterampilan interpersonal, keterampilan presentasi, keterampilan memecahkan suatu masalah dan keterampilan dalam menilai suatu hal.

Dengan adanya keterampilan memecahkan suatu masalah dan menilai suatu hal, diharapkan dalam pembelajaran trigonometri siswa tidak hanya menyelesaikan soal tersebut dengan langkah prosedural saja tetapi juga dapat 
memahami masalah yang disajikan dan dapat memahami manfaat trigonometri dalam kehidupan sehari-hari.

Berbeda dengan Digital Storytelling yang terdapat pada penelitianpenelitian sebelumnya. Pada video Digital Storytelling yang dikembangkan peneliti adalah dengan menambahkan unsur sejarah pada materi trigonometri yang akan dijelaskan. Seperti sejarah penamaan sinus, cosinus, dan tangen. Sejarah penggunaan trigonometri dalam kehidupan dan penemu trigonometri. Dengan menambahkan unsur sejarah, diharapkan minat siswa dalam mempelajari trigonometri juga semakin bertambah sehingga motivasi belajar siswa juga akan meningkat.

Berdasarkan latar belakang di atas, diharapkan melalui penerapan penggunaan media Digital Storytelling ini akan mampu meningkatkan perhatian siswa saat kegiatan pembelajaran sehingga motivasi belajar siswa dalam belajar trigonometri lebih tinggi yang berimplementasi pada peningkatan hasil belajar siswa. Sejalan dengan itu, peneliti tertarik mengambil judul penelitian, "Efektivitas Video Digital Storytelling terhadap Hasil Belajar Siswa Kelas X pada Materi Trigonometri”.

\section{METODE PENELITIAN}

Penelitian ini merupakan penelitian eksperimen dengan pendekatan kuantitatif. Desain yang digunakan dalam penelitian ini menggunakan true experimental design. Sedangkan model yang digunakan dalam design ini adalah model pretest-post test control group design. Dalam penelitian eksperimen, metode ini digunakan untuk mencari pengaruh terhadap perlakuan tertentu yang dikendalikan dalam suatu kondisi (Sugiyono, 2015). Desain pada penelitian ini dapat dilihat pada Tabel 1.

Tabel 1. Desain Penelitian.

\begin{tabular}{cccc}
\hline Kelompok & Pretest & Perlakuan & Posttest \\
\hline K1 & O1 & X1 & O2 \\
K2 & O1 & X2 & O2
\end{tabular}

Keterangan:

K1 : Kelompok kelas eksperimen

K2 : Kelompok kelas kontrol

O1 : Pengukuran kemampuan awal siswa

$\mathrm{O} 2$ : Pengukuran kemampuan akhir siswa

X1 : Pembelajaran dengan perlakuan yaitu penggunaan video digital storytelling.

X2 : Pembelajaran dengan perlakuan yaitu menggunanakan media konvensional (papan tulis dan spidol).

Penelitian ini dilakukan pada bulan Juli-Agustus 2019 pada siswa kelas X SMA Muhammadiyah 4 Surabaya. Populasi pada penelitian ini adalah seluruh siswa kelas X SMA Muhammadiyah 4 Surabaya. Sedangkan Sampel pada penelitian ini diambil dua kelas yaitu kelas X IPA 1 dan X IPA 2. Pengambilan sampel berdasarkan teknik cluster random sampling. Dari dua kelas yang terpilih selanjutnya dipilih secara acak untuk menentukan kelas eksperimen dan kelas kontrol.

Teknik pengumpulan data pada penelitian ini adalah hasil belajar siswa yang dikumpulkan dari perolehan skor pre test dan post test dari masing-masing kelas yaitu kelas eksperimen dan kelas kontrol. Sedangkan data yang sudah terkumpul, selanjutnya data tersebut dianalisis. Teknik analisa data yang digunakan adalah menggunakan analisis deskriptif dan analisis inferensial. 
Analisis deskriptif digunakan untuk mendeskripsikan skor hasil belajar siswa pada masing-masing kelas, baik di kelas eksperimen maupun kelas kontrol. Deskripsi data tersebut dapat berupa nilai minimum, nilai maksimum, nilai rata-rata (mean), dan simpangan baku (standar deviation).

Analisis inferensial digunakan untuk pengujian hipotesis terhadap penelitian. Uji hipotesis yang digunakan menggunakan uji-t yaitu statistik deskriptif untuk melihat perbedaan rata-rata hasil belajar siswa dan uji $\mathrm{N}$-Gain Score dan Independent Sample Test untuk melihat keefektifan Digital Storytelling terhadap hasil belajar siswa. Uji tersebut menggunakan program SPSS 22. Sebelum dilakukan pengujian tersebut, dilakukan uji $N$-Gain Score dan uji prasyarat terlebih dahulu. Uji prasyarat yang dimaksud adalah uji normalitas dan uji homogenitas.

Adapun hipotesis dalam penelitian ini adalah: 1) ada perbedaan hasil belajar siswa antara pembelajaran menggunakan video digital storytelling dengan pembelajaran tanpa menggunakan video digital storytelling, (2) penggunaan video digital storytelling lebih efektif dibandingkan dengan tanpa menggunakan media video digital storytelling terhadap hasil belajar siswa.

\section{HASIL DAN PEMBAHASAN}

Penelitian ini merupakan penelitian eksperimen dengan pendekatan kuantitatif. Penelitian ini dilaksanakan di SMA Muhammadiyah 4 Surabaya dengan sampel sebanyak dua kelas. Sampel pertama yaitu kelas X IPA 1 sebagai kelas eksperimen dan kelas $\mathrm{X}$
IPA 2 sebagai kelas kontrol. Kelas eksperimen di sini dalam pembelajarannya menggunakan media video digital storytelling. Sedangkan kelas kontrol hanya menggunakan media konvensional berupa papan tulis dan spidol saja tanpa menggunakan media video digital storytelling. Jumlah siswa di kedua kelas masing-masing sejumlah 27 siswa.

Video Digital Storytelling yang dikembangkan peneliti terdiri dari 3 macam video. Video pertama membahas tentang sejarah trigonometri dan materi perbandingan trigonometri pada segitiga siku-siku. Pada materi kedua membahas tentang sudut berelasi dan materi ketiga membahas tentang identitas trigonometri. Setiap materi yang dikemas dalam bentuk video digital disajikan dengan durasi 8-19 menit. Dengan masingmasing video dikemas dalam bentuk satu CD yang di akhir pembelajaran CD tersebut dapat dibagikan kepada siswa agar siswa dapat memanfaatkan sebagai bentuk fasilitas belajar yang dapat digunakan di rumah.

Video digital storytelling yang dikembangkan peneliti juga disajikan dengan beberapa tambahan gambar pendukung materi agar siswa dapat lebih tertarik dalam mengikuti pembelajaran di kelas dengan dilengkapi audio sebagai unsur pelengkap yaitu memperjelas bagian-bagian isi yang disajikan dalam video.

Hasil dari penelitian ini didapatkan dari tes hasil belajar siswa yang didapatkan mulai dari sebelum pelaksanaan pembelajaran sampai di akhir setelah pembelajaran berlangsung. Data yang dimaksud adalah nilai pretest dan nilai posttest yang didapatkan dari kedua 
kelas baik kelas eksperimen maupun kelas kontrol.

Pada pertemuan pertama dilakukan tes awal (pretest) untuk mengukur kemampuan awal tentang pemahaman siswa terhadap materi trigonometri pada sub materi: perbandingan trigonometri pada segitiga siku-siku, sudut berelasi, dan identitas trigonometri. Pengambilan data pretest di kedua kelas baik eksperimen maupun kontrol dilaksanakan di hari yang sama. Data pretest dan posttest dari kedua kelas masing-masing disajikan dalam Tabel 2 yang merupakan hasil dari statistik deskriptif hasil belajar siswa selama mengikuti pembelajaran baik dengan menggunakan media video digital storytelling maupun tanpa menggunakan media video digital storytelling.

Tabel 2. Statistik Deskriptif Hasil Belajar Peserta Didik

\begin{tabular}{lccccc}
\hline & N & Min. & Max. & X & $\begin{array}{c}\text { Standar } \\
\text { Deviation }\end{array}$ \\
\hline $\begin{array}{l}\text { Pretest } \\
\text { Eks }\end{array}$ & 27 & 22,85 & 54,28 & 38,19 & 8,68584 \\
$\begin{array}{l}\text { Posttest } \\
\text { Eks }\end{array}$ & 27 & 57,14 & 100,00 & 81,90 & 11,09424 \\
$\begin{array}{l}\text { Pretest } \\
\text { Kontrol }\end{array}$ & 27 & 22,85 & 51,42 & 34,38 & 8,55299 \\
$\begin{array}{l}\text { Posttest } \\
\text { Kontrol }\end{array}$ & 27 & 51,42 & 88,57 & 73,22 & 8,68732 \\
\hline
\end{tabular}

Dari Tabel 2 terlihat nilai rata-rata siswa pada kelas ekperimen dan kelas kontrol sebelum diberikan perlakuan berturut-turut sebesar 38,19 dan 34,38 dengan nilai minimum dan maksimum yang didapatkan siswa pada kelas eksperimen berturut-turut sebesar 22,85 dan 54,28. Sedangkan nilai minimum dan maksimum yang didapatkan siswa pada kelas control berturut-turut sebesar 22,85 dan 51,42 .
Hasil belajar siswa setelah diberikannya perlakuan baik pada kelas eksperimen maupun kelas kontrol mengalami peningkatan. Nilai minimum dan maksimum pada kelas ekperimen berturut-turut sebesar 57,14 dan 100,00 sedangkan nilai minimum dan maksimum pada kelas kontrol sebesar 51,42 dan 88,57. Dari Tabel 2 juga terlihat nilai rata-rata siswa setelah diberikan adanya perlakuan baik dengan media maupun tanpa menggunakan media juga mengalami peningkatan. Rata-rata hasil belajar siswa pada kelas eksperimen sebesar 81,90 dan kelas kontrol sebesar 73,22.

Dari penjelasan di atas terlihat sangat jelas bahwa hasil belajar siswa pada kelas eksperimen lebih tinggi dibandingkan dengan hasil belajar siswa pada kelas kontrol. Sehingga hasil belajar siswa yang diajar dengan menggunakan media video digital storytelling lebih baik dibandingkan hasil belajar siswa yang diajar tanpa menggunakan media video digital storytelling.

Selanjutnya untuk mengetahui keefektifan penggunaan video digital storytelling pada kelas eksperimen dan tanpa penggunaan media video digital storytelling pada kelas kontrol digunakan perhitungan Gain. Hasil dari perhitungan Gain dapat dilihat pada Tabel 3.

Berdasarkan data nilai pretest dan posttest pada kelas ekperimen dan kelas kontrol. Terlihat nilai rata-rata Gain pada kelas eksperimen sebesar 72,11 dan nilai tersebut berdasarkan kategori tafsiran efektivitas $N$-Gain termasuk dalam kategori cukup efektif. Sedangkan nilai rata-rata Gain pada kelas kontrol sebesar 
Tabel 3. Hasil Uji N-Gain Score dalam Persen.

\begin{tabular}{ccc}
\hline & Eksperimen & Kontrol \\
\cline { 2 - 3 } No & N Gain Score & N Gain Score \\
& $\mathbf{( \% )}$ & $\mathbf{( \% )}$ \\
\hline 1 & 69,99 & 56,00 \\
2 & 94,11 & 66,67 \\
3 & 66,67 & 66,67 \\
4 & 61,11 & 65,00 \\
5 & 76,18 & 44,43 \\
6 & 87,49 & 56,51 \\
7 & 77,27 & 53,84 \\
8 & 66,67 & 69,99 \\
9 & 69,57 & 59,08 \\
10 & 57,69 & 62,50 \\
11 & 50,00 & 56,00 \\
12 & 57,13 & 66,67 \\
13 & 61,90 & 73,08 \\
14 & 78,95 & 55,55 \\
15 & 75,99 & 65,38 \\
16 & 74,99 & 61,90 \\
17 & 89,99 & 70,58 \\
18 & 44,45 & 30,43 \\
19 & 84,20 & 59,26 \\
20 & 100,00 & 53,64 \\
21 & 68,18 & 37,03 \\
22 & 69,57 & 59,08 \\
23 & 100,00 & 57,89 \\
24 & 79,99 & 61,11 \\
25 & 80,95 & 69,57 \\
26 & 49,99 & 80,95 \\
27 & 53,84 & 47,99 \\
Xin & 72,11 & 59,52 \\
Maks & 44,45 & 30,43 \\
\hline & 100,00 & 80,95 \\
\hline & &
\end{tabular}

59,52 atau dalam kategori cukup efektif. Meskipun demikian selisih nilai rata-rata Gain cukup besar yaitu sebesar 12,59.

Setelah dilakukan Uji $N$ Gain Score selanjutnya untuk mengetahui apakah perbedaan keefektifan antara pembelajaran yang menggunakan media video digital storytelling dengan pembelajaran yang tanpa menggunakan video digital storytelling tersebut berarti siginifikan atau tidak maka perlu dilakukan Uji Independent Sample Test. Sebelum melakukan Uji t tersebut, sebelumnya dilakukan uji normalitas dan uji homogenitas. Hasil dari uji normalitas dan homogenitas dapat terlihat pada Tabel 4 dan 5 .

Tabel 4. Uji Normalitas

\begin{tabular}{ccccc}
\hline \multirow{2}{*}{ Kelas } & Hasil & \multicolumn{3}{c}{ Shapiro-Wilk } \\
\cline { 3 - 5 } & Belajar & Statistic & df & Sig. \\
& Siswa & & & \\
\hline Eksperi- & Pretest & 0,964 & 27 & 0,455 \\
men & Posttest & 0,960 & 27 & 0,366 \\
Kontrol & Pretest & 0,942 & 27 & 0,134 \\
& Posttest & 0,951 & 27 & 0,225 \\
\hline
\end{tabular}

Berdasarkan dari hasil Uji Normalitas yang terlihat pada Tabel 3, didapatkan nilai signifikansi pretest dan posttest pada kelas eksperimen sebesar 0,455 dan 0,366. Sedangkan nilai signifikansi pretest dan posttest pada kelas kontrol sebesar 0,134 dan 0,225. Dengan membandingkan nilai $\alpha$ sebesar 0,05 maka data hasil belajar siswa saat pretest pada kelas eksperimen yaitu $0,455>0,05$ yang artinya data hasil belajar pretest pada kelas eksperimen berdistribusi normal. Data hasil belajar posttest pada kelas eksperimen yaitu $0,366>0,05$, data hasil belajar pretest pada kelas kontrol yaitu $0,134>0,05$, dan data hasil belajar posttest pada kelas kontrol yaitu 0,225 >0,05. Sehingga dari keempat data tersebut bahwa keempat data hasil belajar tersebut berdistribusi normal.

Setelah dilakukan uji normalitas, selanjutnya untuk mengetahui data tersebut beragam atau tidak maka dilakukan uji homogenitas. Pada uji homogenitas data yang dibandingkan 
adalah data posttest hasil belajar siswa pada kelas eksperimen dan data posttest hasil belajar siswa pada kelas kontrol. Hasil Uji Homogenitas dapat dilihat pada Tabel 5.

Tabel 5. Uji Homogenitas

\begin{tabular}{lcccc}
\hline $\begin{array}{c}\text { Hasil } \\
\text { Belajar } \\
\text { Siswa }\end{array}$ & $\begin{array}{c}\text { Levene } \\
\text { Statistic }\end{array}$ & df1 & df2 & Sig. \\
\hline Pretest & 0,927 & 1 & 52 & 0,340 \\
Posttest & 1,045 & 1 & 52 & 0,311 \\
Pretest & 1,045 & 1 & 49,29 & 0,312 \\
Posttest & 0,975 & 1 & 52 & 0,328 \\
\hline
\end{tabular}

Berdasarkan dari hasil uji homogenitas yang terlihat pada Tabel 5, nilai tes akhir (posttest) antara kelas eksperimen dan kelas kontrol diperoleh 0,340. Dengan membandingkan nilai signifikansi tersebut dengan nilai $\alpha$ sebesar 0,05 maka terlihat bahwa $0,340>0,05$ yang artinya data tersebut adalah homogen atau berasal dari populasi dengan varians yang sama.

Tahap terakhir adalah dengan melakukan uji hipotesis yaitu uji $\mathrm{t}$ menggunakan Independent Sample Test. Uji ini digunakan pada dua sampel yang tidak berpasangan yaitu antara kelas eksperimen dan kelas kontrol. Untuk mengetahui apakah ada perbedaan ratarata hasil belajar siswa pada kelas eksperimen dengan kelas kontrol, maka hipotesis penelitiannya adalah sebagai berikut.

Ho : Tidak ada perbedaan rata-rata hasil belajar siswa antara kelas eksperimen dengan kelas kontrol.

Ha : Ada perbedaan rata-rata hasil belajar siswa antara kelas eksperimen dengan kelas kontrol.
Dasar pengambilan keputusan keputusan Uji Independent Sample $T$ Test adalah sebagai berikut.

1. Jika nilai sig. (2 tailed) $>0,05$ maka Ho diterima dan Ha ditolak.

2. Jika nilai sig. (2 tailed) $<0,05$ maka Ho ditolak dan Ha diterima.

(Prasetyowati, 2016).

Tabel 6: Uji Independent Sample T Test

\begin{tabular}{|c|c|c|c|c|c|c|}
\hline & & \multicolumn{5}{|c|}{ t-test equality of means } \\
\hline & & \multicolumn{3}{|c|}{$\begin{array}{c}\text { Sig }(2 \text { tailed }) \\
\text { Mean Differences } \\
\text { Standar error difference }\end{array}$} & \multicolumn{2}{|c|}{$\begin{array}{l}95 \% \text { confidence } \\
\text { interval of the } \\
\text { difference }\end{array}$} \\
\hline & & & & & lower & upper \\
\hline \multirow[t]{2}{*}{$\begin{array}{c}\text { Hasil } \\
\text { belajar } \\
\text { siswa }\end{array}$} & $\begin{array}{c}\text { Equal } \\
\text { Variances } \\
\text { assumed }\end{array}$ & 0,002 & 8,678 & 2,712 & 3,236 & 14,119 \\
\hline & $\begin{array}{c}\text { Equal } \\
\text { Variances } \\
\text { not } \\
\text { assumed }\end{array}$ & 0,002 & 8,678 & 8,678 & 3,229 & 14,127 \\
\hline
\end{tabular}

Dari Tabel 6, pada bagian equal variances assumed terlihat bahwa nilai signifikansi 0,002 dimana 0,002 <0,05 sehingga Ho ditolak dan Ha diterima. Artinya ada perbedaan rata-rata hasil belajar antara pembelajaran yang menggunakan media video digital storytelling dengan pembelajaran yang tanpa menggunakan media video digital storytelling. Karena adanya perbedaan hasil belajar tersebut, sehingga dapat dikatakan bahwa media video digital storytelling efektif digunakan.

Perbedaan hasil belajar tersebut sebesar 8,678 . Sehingga dari sini dapat kita simpulkan bahwa penggunaan media video digital storytelling lebih efektif dibandingkan pembelajaran yang tidak menggunakan video digital storytelling.

Berdasarkan pemaparan data di atas, yang ditunjukkan dari hasil uji Independent Sample Test didapatkan bahwa ada perbedaan signifikansi dalam hal hasil belajar siswa pada siswa yang 
belajar dengan menggunakan media video digital storytelling dengan siswa yang belajar tanpa video digital storytelling. Selain itu penggunaan media video digital storytelling terbukti lebih efektif dibandingkan pembelajaran yang tidak menggunakan video digital storytelling.

Hal ini sesuai dengan pernyataan Heriyana dan Maureen dalam Asri (2017) yang menyatakan bahwa digital storytelling memiliki enam manfaat yaitu kreativitas dan inovasi; komunikasi dan kolaborasi; penelitian dan kelancaran informasi; berpikir kritis, pemecahan masalah, dan pengambilan keputusan; masyarakat digital, pengoperasian teknologi dan konsep. Sukirman (2016) pada penelitiannnya juga menjelaskan bahwa siswa lebih suka diajar dengan digital storytelling dibandingkan dengan cara lisan. Suasana pembelajaran juga lebih aktif dan menggembirakan karena terdapat interaksi antara seluruh audiens dan storyteller.

Di samping penggunaan media digital storytelling yang dapat membantu siswa dalam memecahkan suatu masalah, digital storytelling juga efektif digunakan dalam pembelajaran dikarenakan dalam penggunaannya menggabungkan antara cerita yang berisikan gambar dan suara yang bisa diisi oleh seorang native speaker maupun suara Guru. Hal ini sesuai dengan penjelasan Robin dalam (Qoidah, 2018) yang menyatakan bahwa, "digital storytelling revolved around the idea of combining the art of telling stories with a variety of digital multimedia, such as image, audio, and video".
Dari penjelasan di atas, seorang guru harus dapat lebih kreatif lagi dalam mengelola pembelajaran di kelas agar pembelajaran lebih menyenangkan dan tidak membuat siswa bosan. Penggunaan media menjadi salah satu alternatif bagi guru untuk dapat membuat siswa tertarik dalam pembelajaran dan dapat meningkatkan siswa dalam suatu pemahaman terhadap materi yang diajarkan.

Pernyataan di atas diperkuat juga oleh pendapat Baylor \& Richie dalam (Surwantini, 2015) yang menyatakan bahwa guru yang menggunakan media pembelajaran saat kegiatan pembelajaran di kelas dapat mempertahankan perhatian siswa, meningkatkan pemahaman konsep-konsep abstrak, mendorong pemrosesan lebih dalam dan dapat meningkatkan kinerja kelas. Artinya, dengan guru menggunakan media di dalam proses pembelajaran dapat membantu siswa dalam memahami suatu permasalahan yang tadinya masih abstrak menjadi lebih jelas dan menarik.

Sehingga dalam hal ini, penggunaan digital storytelling sebagai media pembelajaran trigonometri sangatlah efektif digunakan, karena tidak hanya membuat pembelajaran di kelas lebih menarik tetapi juga dapat membantu siswa dalam memahami materi yang abstrak dan dapat menjelaskan kepada siswa tentang manfaat trigonometri dalam kehidupan sehari-hari melalui konten yang disajikan yaitu penyajian sejarah trigonometri di dalam video digital storytelling yang berimplikasi pada peningkatan hasil belajar siswa terhadap pembelajaran trigonometri. 


\section{PENUTUP}

Berdasarkan hasil penelitian dan pembahasan di atas, maka dapat disimpulkan bahwa: 1) ada perbedaan rata-rata hasil belajar siswa yang menggunakan video digital storytelling dengan siswa yang saat pembelajaran tanpa menggunakan video digital storytelling pada materi trigonometri di SMA Muhammadiyah 4 Surabaya, dan (2) penggunaan media video digital storytelling lebih efektif digunakan saat pembelajaran trigonometri dibandingkan pembelajaran yang tidak menggunakan media video digital storytelling.

Saran dari hasil penelitian adalah sebagai berikut. 1) Dalam proses pembelajaran, sebaiknya guru dapat menggunakan media yang lebih inovatif dan dapat menarik minat siswa dalam belajar. 2) Salah satu media yang dapat digunakan Guru adalah media video digital storytelling. 3) Durasi video digital storytelling sebaiknya tidak terlalu lama agar siswa juga tidak terlalu jenuh saat memperhatikan video. 4) Pembuatan video digital storytelling sebaiknya memperhatikan beberapa unsur artistic, seperti gambar yang menarik, unsur warna, penataan, maupun saat rekaman suara agar dapat membuat siswa lebih termotivasi untuk belajar.

\section{DAFTAR PUSTAKA}

Anggadewi, Brigita ET. (2017). Digital Storytelling Sebagai Media Guru Untuk Mengembangkan Komunikasi Anak Berkebutuhan Khusus. Prosiding Temu Ilmiah X Ikatan Psikologi Perkembangan Indonesia. ISBN: 978-602-114549-4. (online)
Asri, Atiqah Nurul., dkk. (2017). Penerapan Digital Storytelling Dalam Pembelajaran Bahasa Inggris di Program Studi Manajemen Informatika. www.researchgate.net/publication /329642196. (online)

Djamarah, Syaiful Bahri. \& Zain, Aswan. (2010). Strategi Belajar Mengajar. Jakarta: Rineka Cipta.

Eggen, P. \& Kauchak, D. (2012). Strategi dan Model Pembelajaran: Mengajarkan Konten dan Keterampilan Berpikir Edisi Keenam Terjemahan: Satrio Wahono. Jakarta: Permata Puri Media. Boston: Pearson Education.

Krisnawati, Endang. \& Julianingsih, Denok. (2019). Efektivitas Penggunaan Video Digital Storytelling Pada Materi Trigonometri di Kelas X Untuk Meningkatkan Motivasi Belajar Siswa. JP3M (Jurnal Penelitian Pendidikan dan Pengajaran Matematika) Vol 5. No. 2, PP. 55 -62. (online)

Prananta, Yunina Resmi, dkk. (2017). Pengembangan Media Boneka Tangan Berbasis Digital Storytelling. JPTPP (Jurnal Pendidikan Teori, Penelitian, dan Pengembangan) Vol. 2. No.5 Mei hal. 627 - 636. EISSN: $2502-$ 471X. (online)

Prananta, Yunina Resmi. (2016). Pemanfaatan Digital Storytelling Sebagai Media Pembelajaran Tematik di SD. Seminar Inovasi Pendidikan di Era Big Data dan aspek psikologinya. digilib.mercubuana.ac.id. (online)

Prasetyowati, Didin Astriani. (2016). Analisis Statistik-Teori dan Aplikasi Menggunakan SPSS 
(ebook). Fakultas Ilmu Komputer - Universitas Indo Glonal Mandiri Palembang.

Purwanti, Budi. (2015). Pengembangan Media Video Pembelajaran Matematika dengan Model Assure. Jurnal Kebijakan dan Pengembangan Pendidikan. Vol. 3 no. 1 Januari hal $42-47$. ISSN: 2337-7623, EISSN: 2337-7615. (online)

Rohmawati, Rizka Novia. (2014). Keefektifan Digital Storytelling Dalam Pembelajaran Biologi Untuk Siswa SMA Pada Materi Bioteknologi. Jurnal BIOEDU (Berkala Ilmiah Pendidikan Biologi). Vol 3 no. 3 Agustus. ISSN: 2302-9528. (online)

Sugiyono. (2015). Metode Penelitian Kuantitatif, Kualitatif, dan R\&D. Bandung: Alfabeta.
Sukirman. (2016). Digital Storytelling Interaktif dan Menggembirakan Menggunakan Augmented Reality. Prosiding Seminar Nasional ELINVO. ISSN: 24772402

Surwantini, Eti. (2015). Efektivitas Penggunaan Media Visual Terhadap Motivasi Belajar dan Prestasi Belajar Siswa Kelas III SD Gugus 01 Imogiri, Bantul. Jurnal Penelitian Ilmu Pendidikan. Vol.8 no. 2, September. DOI: https://doi.org/10.21831/jpipfip.v8 i2.8273. (online)

Qoidah, Riana Fathonatul. (2018). Efektivitas Penggunaan Media Digital Storytelling Dalam Pembelajaran Menulis Teks Narrative: Studi Kasus di SMP Negeri 1 Widodaren Ngawi. Prosiding Seminar Nasional $K A L U N I$ Vol.1. (online) 